\title{
TANGGUNG JAWAB NEGARA PELUNCUR TERHADAP SAMPAH RUANG ANGKASA
}

\author{
Dony Aditya Prasetyo \\ Fakultas Hukum Universitas Brawijaya \\ J1. MT. Haryono 169 Malang \\ Email: donyaprasetyo@gmail.com
}

\begin{abstract}
There is an increace of state activity on outer space every year. Each activity has concequences. One of these concequenses is the increase of space debris. Space debris which is produced by outer space state activity could be caused by space junk or other space object that have expired. Those space object stay on the earth orbit for a long period. State has the responsibility to keep their activities according to the magna carta of outer space law called the Outer Space Treaty. In this case, states which conduct their activities on outer space and produce space debris have failed to conduct their obligation to maintain the outer space that is a common heritage of mankind. The area must be available for future uses. There is a need for a new international instrument to control the population of space debris. This jurnal uses normative legal research method and statute approach, mainly international agreements related to space law.
\end{abstract}

Key words: state responsibility, space debris, launching state, space law

\begin{abstract}
Abstrak
Kegiatan negara di ruang angkasa hingga saat ini telah ribuan kali jumlahnya. Semua kegiatan tersebut tentunya memiliki konsekuensi yang harus dihadapi. Salah satu akibat dari maraknya kegiatan negara di ruang angkasa adalah makin banyaknya sampah yang berasal dari hasil kegiatan negara. Sampah ruang angkasa tersebut terdiri dari benda-benda sisa kegiatan ataupun benda angkasa yang tadinya digunakan namun masa hidupnya telah habis sehingga dibiarkan begitu saja keberadaannya di ruang angkasa. Pada hal ini, negara telah lalai menjalankan tanggung jawabnya yakni menjaga supaya ruang angkasa yang merupakan milik bersama umat manusia tetap terjaga keberadaannya dengan baik. Hal tersebut bertujuan supaya ruang angkasa tetap menjadi wilayah yang layak untuk digunakan hingga waktu yang akan datang. Diperlukan instrumen hukum internasional yang baru untuk mengatur keberadaan sampah ruang angkasa tersebut.Metode yang digunakan adalah yuridis normatif dengan pendekatan terhadap peraturan hukum tertulis terutama Perjanjian Internasional yang berhubungan dengan Hukum Ruang Angkasa
\end{abstract}

Kata kunci: tanggung jawab negara, negara peluncur, sampah ruang angkasa

\section{Latar Belakang}

Teknologi selalu berkembang pesat dari masa ke masa. Perkembangan teknologi yang demikian cepat dan pesatnya ini telah merambah berbagai bidang dalam segala aspek kehidupan. Hampir segala sisi kehidupan kini melibatkan penggunaan teknologi. Dengan adanya teknologi yang semakin canggih dari 
waktu ke waktu semakin mempermudah pekerjaan manusia yang menggunakannya. Salah satu bentuk kemajuan teknologi adalah maraknya kegiatan manusia melakukan eksplorasi di ruang angkasa, salah satunya adalah dengan meluncurkan satelit untuk mendukung kegiatan mereka di bumi.

Sejak pertama kali satelit Sputnik I milik Rusia diluncurkan hingga saat ini, ada ribuan satelit yang terdata telah mengorbit di permukaan bumi. Menurut data yang dirilis oleh United State Space Surveillance Network (SSN), sebuah lembaga yang bertugas melacak satelit di orbit bumi, ada sekitar 3000 satelit dari total 8000 objek buatan manusia. ${ }^{1}$ Meski demikian, SSN telah mencatat sejumlah 24.500 obyek yang pernah diluncurkan di mana sebagian besar telah jatuh ke bumi dan terbakar di atmosfer. Bahkan Sputnik I milik Rusia yang diluncurkan pada tahun 1957 ditengarai masih mengorbit.

Sejalan dengan semakin banyaknya tipe satelit dan juga negara yang terlibat dalam peluncuran ataupun pemilikan satelit, maka diperlukan pula kebutuhan akan prinsipprinsip yang lebih tegas menganai kegiatan di ruang angkasa. Untuk hal inilah kemudian muncul suatu kaidah-kaidah pengaturan yang disebut sebagai Hukum Ruang Angkasa. Hukum ruang angkasa adalah hukum yang ditujukan untuk mengatur hubungan antar negara-negara, untuk menentukan hak-hak dan kewajiban-kewajiban yang timbul dari segala aktivitas yang tertuju kepada ruang angkasa dan di ruang angkasa dan aktivitas itu demi kepentingan seluruh umat manusia, untuk memberikan perlindungan terhadap kehidupan, terrestrial dan non-terrestrial, di mana-pun aktivitas itu dilakukan. ${ }^{2}$ Inilah sebabnya kemudian disebutkan bahwa ruang angkasa adalah common heritage of mankind, atau warisan bersama milik seluruh umat manusia.

Meningkatnya teknologi berpengaruh pada intensitas kegiatan negara di ruang angkasa. Selama 50 tahun berbagai penelitian untuk menunjang kegiatan manusia di ruang angkasa dilakukan, selama itu pula semakin banyak satelit yang diluncurkan oleh negaranegara. Banyaknya satelit tersebut juga mengakibatkan bertambahnya populasi dari sampah ruang angkasa, terutama dari satelitsatelit yang sudah tidak dapat beroperasi lagi dengan sebagaimana mestinya. ${ }^{3}$

Keberadaan satelit-satelit tidak terpakai inilah yang kemudian ditakutkan akan mengganggu kegiatan ruang angkasa, utamanya satelit lain yang masih beroperasi dan bekerja sebagaimana mestinya. Meskipun satelit telah tidak beroperasi lagi, tetap saja

1 Amazine, "Berapa Jumlah Satelit Yang Mengorbit Bumi”, http://www.amazine.co/14488/berapa-jumlahsatelit-yang-mengorbit-bumi/, diakses 28 Maret 2015.

2 Diederiks-Verschoor, Beberapa Persamaan dan Perbedaan Antara Hukum Udara dan Hukum Ruang Angkasa, terjemahan oleh Bambang Iriana, (Jakarta: Sinar Grafika, 1991), hlm. 7.

3 H. G. Lewis, G. G. Swinerd and R. J. Newland, "Space Debris Represents a Significant Risk to Satellite Operations", Aeronautical Journal (2011): 1166. 
benda-benda angkasa tersebut akan selalu mengikuti orbit bumi, tidak kemudian serta merta berhenti dengan sendirinya. Orbit bumi pada kenyataannya adalah berbentuk hampir lingkaran yang dekat dengan garis tengah bumi. Maka hampir semua benda angkasa berupa satelit yang diluncurkan mengorbit pada lintasan yang sama. ${ }^{4}$

Seorang ahli antariksa asal NASA, Donald J Kessler pada tahun 1978 pernah mengajukan sebuah pendapat berkenaan dengan keberadaan sampah ruang angkasa. Dengan semakin banyaknya satelit tidak beroperasi yang tetap mengorbit di ruang angkasa, hal tersebut akan membahayakan keberadaan satelit lain yang masih beroperasi. Meskipun kemudian terjadi tabrakan antar satelit yang tidak lagi beroperasi, harus diperhatikan ke mana pecahan-pecahan benda angkasa yang hancur akibat tebrakan tersebut. Tentunya pecahan tersebut akan tetap berada di orbit dan berpotensi menabrak benda angkasa yang lainnya. Semakin banyak pecahan yang berserakan, semakin berbahaya pula bagi setiap negara yang berkegiatan di ruang angkasa. Efek berantai yang pada kemudian hari disebut sebagai Kessler Effect. ${ }^{5}$ Bukan tidak mungkin juga jika pecahan-pecahan tersebut kemudian berjatuhan ke bumi dan membahayakan kehidupan manusia di permukaan bumi.
Tidak adanya regulasi yang membatasi kegiatan negara untuk meluncurkan satelit diyakini akan semakin meramaikan jumlah satelit yang mengorbit. Perkembangan teknologi yang ada sekarang ini hampir semuanya membutuhkan satelit untuk menghadirkan kemudahan bagi manusia. Baik itu kegiatan yang berhubungan dengan komunikasi hingga keinginan negara maju untuk memperkuat pertahanan negaranya melalui kemampuan mereka menguasai ruang angkasa. Hal-hal yang tentunya harus mulai dipikirkan dengan baik oleh negara pengguna ruang angkasa.

Saat Donald J Kessler masih menjabat sebagai direktur NASA, pembicaraan tentang kemungkinan bahaya akibat sampah ruang angkasa selalu berusaha dibahas olehnya. Namun sejak Kessler berhenti menjabat sebagai direktur NASA, pembicaraan mengenai keberadaan sampah ruang angkasa ini hampir tidak pernah dibicarakan lagi. NASA lebih sibuk dengan misi-misi untuk mencari sumber kehidupan baru di ruang angkasa. ${ }^{6}$

Panduan utama negara-negara untuk melakukan kegiatan di ruang angkasa terdapat pada sebuah prinsip-prinsip berkegiatan di ruang angkasa yang disebut Treaty on Principles Governing the Activities of States in the Exploration and Use of Outer Space,

4 Karl Tate, "Space Junk Explained: How Orbital Debris Threatens Future of Spaceflight", http://www.space. com/23039-space-junk-explained-orbital-debris-infographic.html, diakses 28 Maret 2015.

5 Michelle La Vone, "The Kessler Syndrome: 10 Interesting and Disturbing Facts", http://www. spacesafetymagazine.com/space-debris/kessler-syndrome/, diakses 28 Maret 2015.

6 Futurism, "The Seriousness of the Kessler Syndrome", http://futurism.com/the-seriousness-of-the-kesslersyndrome/, diakses 28 Maret 2015. 
including the Moon and Other Celestial Body 1967 atau biasa disingkat Outer space treaty 1967. Hanya saja isi dari perjanjian ini masih merupakan hal-hal yang sangat bersifat umum. Kemajuan teknologi ruang angkasa yang berkembang hingga saat ini membutuhkan penafsiran lagi dari berbagai pihak yang melakukan kegiatan di angkasa apakah sesuai atau tidak dengan isi dari prinsip-prinsip tersebut. Begitupun ketidakhadiran pengertian terhadap sampah ruang angkasa.

Menurut beberapa ahli angkasa, sampah ruang angkasa adalah obyek apapun termasuk satelit, baik itu yang berawak maupun tidak berawak yang terdiri dari dua jenis: ${ }^{7}$

Benda tersebut masih mengorbit pada lintasannya namun sudah tidak berfungsi atau tidak difungsikan lagi oleh pemiliknya

Benda tersebut tidak lagi mengorbit namun masuk kembali ke atmosfer bumi.

Pada intinya adalah saat benda-benda yang ada di orbit bumi tersebut tidak lagi memiliki kegunaan maupun fungsi maka pada saat itulah benda tersebut dapat dikategorikan sebagai sampah ruang angkasa. Ukuran dari sampah ruang angkasa itu sendiri bermacammacam. Bisa hanya sekian millimeter hingga benda besar berukuran ratusan meter. Sampah ruang angkasa tersebut meliputi satelit yang sudah tidak aktif, badan roket yang digunakan untuk meluncurkan satelit, pecahan badan roket yang digunakan untuk meluncurkan satelit, pecahan akibat tabrakan antar benda angkasa, maupun benda hasil kegiatan lain yang tertinggal di ruang angkasa. ${ }^{8}$

Banyaknya sampah ruang angkasa yang bertebaran di orbit bumi menjadi sebuah permasalahan yang serius setelah terjadi beberapa kasus. Pada tanggal 11 Februari 2009, kasus tabrakan antar satelit pertama kali terjadi antara satelit komunikasi milikAmerika dengan satelit milik Rusia yang terindikasi sudah tidak aktif lagi. Tabrakan tersebut ditengarai terjadi di atas wilayah Siberia. Efek dari tabrakan tersebut mengakibatkan kabut pekat mirip awan mendung di atas wilayah utara Siberia. ${ }^{9}$ Hanya saja tabrakan tersebut melibatkan dua satelit yang sama-sama sudah tidak berfungsi, sehingga tidak menimbulkan masalah yang besar.

Kasus terbaru terjadi pada tahun 2013 yang melibatkan satu-satunya satelit milik Ekuador dengan pecahan tangki bahan bakar roket milik Rusia. ${ }^{10}$ Ini adalah kali pertama tabrakan antar satelit melibatkan satelit yang masih berfungsi dan digunakan. Keinginan negara pengguna supaya orbit ruang angkasa menjadi tempat yang aman semakin meningkat.

Permasalahan muncul jika mengacu pada

7 Stella Tchatkova, "Space Based Technology and Commercials Development”, Engineering Science Reference, (2011): 286.

8 Michael J. Listner, "Legal Issues Surrounding Space Debris Remediation,” http:/www.thespacereview.com/ article/2130/1, diakses 26 Maret 2015.

9 BBC, "Russian and US Satellite Collide”, http://news.bbc.co.uk/2/hi/7885051.stm, diakses 28 Maret 2015.

10 BBC, "Ecuador Pegasus Satellite Fears Over Space Debris Crash," http://www.bbc.com/news/world-latinamerica-22635671, diakses 28 Maret 2015. 
pasal 8 Outer space treaty 1967. Pada pasal tersebut tertulis sebagai berikut,

"A State Party to the Treaty on whose registry an object launched into outer space is carried shall retain jurisdiction and control over such object, and over any personnel thereof, while in outer space or on a celestial body. Ownership of objects launched into outer space, including objects landed or constructed on a celestial body, and of their component parts, is not affected by their presence in outer space or on a celestial body or by their return to the Earth. Such objects or component parts found beyond the limits of the State Party to the Treaty on whose registry they are carried shall be returned to that State Party, which shall, upon request, furnish identifying data prior to their return."

Pasal tersebut jelas menyatakan bahwa negara peluncur adalah pihak yang memiliki yurisdiksi atas benda angkasa yang diluncurkannya. Benda angkasa yang diluncurkan tersebut tetap menjadi milik negara peluncur hingga kapanpun. Hal ini menyebabkan tidak ada negara manapun yang dapat menyingkirkan sampah ruang angkasa tersebut kecuali pemilik benda angkasa tersebut sendiri. Permasalahannya adalah tidak semua negara peluncur memiliki teknologi atau kemampuan untuk melakukan hal tersebut. Pada akhirnya mereka lebih memilih untuk membiarkan satelit yang tidak berfungsi tersebut tetap berada di orbit.
Resikonya seperti yang telah diungkapkan sebelumnya, dapat mengakibatkan tabrakan dengan benda angkasa yang lain.

Pada tahun 1984, Indonesia pernah meluncurkan sebuah satelit dengan nama Palapa B2. Namun pada proses diluncurkannya satelit tersebut menuju orbit, terjadi kegagalan pada mesin roket pendorongnya sehingga gagal mencapai titik orbit yang dikehendaki. Satelit tersebut memang berhasil mengorbit namun karena bukan pada titik yang semestinya, Palapa B2 menjadi tidak berfungsi. Pada saat itu sebuah perusahaan asal Amerika membeli satelit yang tidak berfungsi tersebut karena dirasa membahayakan satelit lain yang masih berfungsi. Pembelian tersebut dengan tujuan mengalihkan kepemilikan Indonesia kepada Amerika sehingga satelit tersebut bisa diambil dari orbit. ${ }^{11}$

Permasalahan yang muncul di sini adalah, dari beberapa ilustrasi kasus yang disebutkan maka bisa disebutkan bahwa keberadaan sampah ruang angkasa adalah suatu hal yang cukup berbahaya pagi negara lain yang berkegiatan di ruang angkasa. Tentunya melakukan kegiatan apapun di ruang angkasa menghasilkan konsekuensi bagi negara peluncur. Jika kemudian benda angkasa yang diluncurkan tidak berfungsi lagi, bagaimana bentuk tanggung jawab negara peluncur terhadap sampah ruang angkasa tersebut.

Tidak adanya peraturan yang berbicara

11 Sattel Technologies, “The Historic Journey of Palapa B2,” http://www.sattel.com/life_of_palapa_b2.htm, diakses 28 Maret 2015. 
khusus tentang keberadaan sampah ruang angkasayangmenjadihasildarikegiatannegara di ruang angkasa juga menjadi permasalahan tersendiri. Semakin berkembangnya kegiatan di ruang angkasa tentunya membutuhkan regulasi-regulasi berkelanjutan supaya negara manapun tetap terjamin keselamatannya dalam berkegiatan di ruang angkasa.

Jenis tulisan ini adalah Yuridis Normatif. Penulis menggunakan metode pendekatan Normatif karena penulis menggunakan datadata maupun dokumen tertulis terutama perjanjian induk yang merupakan panduan berkegiatan Negara di ruang angkasa yakni Treaty on Principles Governing the Activities of States in the Exploration and Use of Outer Space, including the Moon and Other Celestial Bodies, untuk menjelaskan bentuk tanggung jawab negara peluncur terhadap sampah ruang angkasa yang dihasilkan dari kegiatan di ruang angkasa menurut hukum ruang angkasa dan apakah diperlukan peraturan baru untuk mengatur dan mengontrol keberadaan sampah ruang angkasa.

Pendekatan yang digunakan dalam tulisan ini adalah pendekatan statute approach. Pendekatan ini digunakan karena untuk melakukan pengkajian terhadap permasalahan yang muncul adalah dengan melihat kepada peraturan atau instrumen hukum internasional yang ada. Pada tulisan ini difokuskan pada Outer space treaty 1967 yang merupakan induk dari kegiatan negara di ruang angkasa. Dengan menggunakan instrumen hukum tersebut diharapkan dapat menjawab permasalahan yang muncul yakni apakah tanggung jawab negara peluncur di ruang angkasa telah sesuai dengan yang dikehendaki oleh hukum ruang angkasa. Setelah mengetahui jawaban dari permasalahan tersebut maka dapat disimpulkan apakah kemudian diperlukan instrumen hukum baru untuk mengontrol dan mengawasi keberadaan sampah di ruang angkasa.

\section{Pembahasan}

\section{A. Tanggung Jawab Negara Peluncur terhadap Sampah Ruang Angkasa yang Dihasilkan dari Kegiatan Ruang Angkasa Belum Sesuai dengan Hukum Ruang Angkasa}

Subyek Hukum Internasional yang paling utama adalah negara. ${ }^{12}$ Ini ditunjukkan dengan adanya sebuah kedulatan yang dimiliki oleh suatu negara sejak negara itu dilahirkan. Meskipun sebuah negara tersebut dinilai memiliki sebuah kekuasaan tertinggi yang disebut kedaulatan, bukan berarti kemudian negara tersebut dapat berbuat semaunya. Hal ini dikarenakan kedaulatan tersebut sesungguhnya bukanlah sesuatu yang sifatnya tak terhingga. Kedaulatan sebuah negara adalah tidak tak terbatas. ${ }^{13}$

Terdapat satu hal yang menjadi batas dari

12 J.G Starke, Pengantar Hukum Internasional, (Jakarta: Sinar Grafika, 2010), hlm. 132.

13 Dedi Supriyadi, Hukum Internasional dari Konsepsi sampai Aplikasi, (Bandung: Pustaka Setia, 2013), hlm. 126. 
kedaulatan suatu negara, yakni kedaulatan negara yang lainnya. Kedaulatan negara dapat berakhir pada saat bertemu dengan kedulatan negara yang lainnya. Hukum internasional berdasar pada adanya saling ketergantungan dan kebutuhan antara satu negara dengan negara yang lainnya. Hukum Internasional adalah suatu hukum yang bersifat koordinasi, bukan subordinasi. Ini menunjukkan bahwa semangat yang dibawa oleh hukum internasional adalah semangat kebersamaan dan semangat kesederajatan. Menjadi tetangga yang baik bagi negara lain adalah suatu keharusan.

Sebagai suatu bentuk perwujudan sebagai tetangga yang baik tersebut maka setiap negara yang ada di dunia memiliki tanggung jawab yang harus dipikul untuk menjaga semangat kesederajatan dan kebersamaan tersebut. Hukum Internasional sendiri mengenal dua macam tanggung jawab negara. Dua macam tanggung jawab tersebut yakni:

a. Kewajiban melaksanakan berbagai perjanjian internasional

b. Kewajibanmengatasipersoalan-persoalan pelanggaran yang menyebabkan kerugian pada subjek hukum internasional, baik itu negara, individu, organisasi internasional maupun perusahan-perusahan nasional dan multi nasional.

Ciri-ciri esensial pertanggungjawaban berhubungan dengan beberapa faktor dasar. Faktor-faktor tersebut antara lain: ${ }^{14}$ a. Adanya kewajiban hokum internasional yang masih berlaku di antara kedua Negara yang bersangkutan

b. Bahwa telah terjadi suatu perbuatan atau kelalaian yang melanggar kewajiban itu dan mewajibkan Negara tersebut bertanggung jawab

c. Bahwa perbuatan melanggar hukum atau kelalaian tersebut menimbulkan kehilangan atau kerugian

Merujuk pada macam tanggung jawab di atas maka dapat disebutkan bahwa ada dua tanggung jawab yang dapat lahir dari kegiatan internasional. Kewajiban yang lahir karena mematuhi hukum internasional, serta kewajiban untuk memulihkan kerugian yang dihasilkan oleh suatu negara yang merugikan subjek hukum internasional yang lain.

Hukum internasional telah memiliki suatu instrumen yang memberikan pedoman terhadap negara ataupun pihak yang ingin menggunakan ruang angkasa sebagai lokasi kegiatannya. Peraturan tersebut berjudul Treatyon Principles Governingthe Activitiesof Statesinthe Explorationand Use of Outer Space Including the Moon and Other Celestial Bodies, atau lebih sering disebut sebagai Outer space treaty 1967. Konvensi ini menyetujui prinsip-prinsip untuk ditaati para negara pengguna ruang angkasa.

Pada Outer space treaty 1967 yang menjadi induk prinsip-prinsip berkegiatan negara di ruang angkasa, serta bahan hukum primer 
pada penelitian ini, pasal VI menyebutkan:

"States Parties to the Treaty shall bear international responsibility for national activities in outer space, including the Moon and other celestial bodies, whether such activities are carried on by governmental agencies or by non-governmental entities, and for assuring that national activities are carried out in conformity with the provisions set forth in the present Treaty. The activities of non-governmental entities in outer space, including the Moon and other celestial bodies, shall require authorization and continuing supervision by the appropriate State Party to the Treaty. When activities are carried on in outer space, including the Moon and other celestial bodies, by an international organization, responsibility for compliance with this Treaty shall be borne both by the international organization and by the States Parties to the Treaty participating in such organization."

Atau jika diterjemahkan, negara anggota perjanjian ini mengemban tanggung jawab internasional dalam aktivitasnya di ruang angkasa baik kegiatan tersebut dilakukan oleh pemerintah ataupun bukan. Jika kegiatan di ruang angkasa dilakukan bukan oleh pemerintah maka tetap diperlukan adanya ijin serta pengawasan oleh Negara peserta perjanjian.

Sementara itu pada pasal VII disebutkan

"Each State Party to the Treaty that launches or procures the launching of an object into outer space, including the Moon and other celestial bodies, and each State Party from whose territory or facility an object is launched, is internationally liable for damage to another State Party to the Treaty or to its natural or juridical persons by such object or its component parts on the Earth, in air space or in outer space, including the Moon and other celestial bodies."

Atau jika diterjemahkan, semua Negara anggota perjanjian yang melakukan peluncuran benda angkasa, secara internasional mengemban tanggung jawab atas segala kerusakan yang mengakibatkan kerugian pada Negara lain di wilayah bumi, udara maupun di wilayah ruang angkasa itu sendiri.

Pada dua pasal ini terdapat pembedaan antara istilah "international responsibility" dan "internationally liable". Hal ini memperkuat pendapat sebelumnya mengenai dua macam tanggung jawab yang lahir pada hukum internasional. Untuk kepentingan menjawab rumusan permasalahan yang pertama ini, tanggung jawab yang dimaksud adalah tanggung jawab pada pengertian pertama, yakni kewajiban untuk melaksanakan perjanjian internasional.

Pasal VI menyebutkan bahwa semua kegiatan nasional yang dilakukan oleh suatu negara di ruang angkasa menjadikannya memiliki tanggung jawab secara internasional. Jika kemudian Pasal VI tersebut dibagi ke dalam beberapa unsur maka akan menjadi seperti berikut:

1. Bahwa setiap negara bertanggung jawab 
atas aktivitas negara di ruang angkasa baik oleh badan hukum publik maupun privat.

2. Untuk memastikan supaya aktivitas negara sesuai dengan apa yang diinginkan oleh Outer space treaty, terutama Pasal III, dan juga Hukum Internasional.

3. Untuk memberikan ijin dan pengawasan yang berkesinambungan atas aktivitas organisasi non-pemerintah di ruang angkasa.

4. Untuk membagi tanggung jawab internasional atas kegiatan di ruang angkasa oleh Organisasi Internasional di mana suatu negara tersebut berpartisipasi.

Mengacu pada Pasal VI maka sesungguhnya setiap negara yang melakukan aktivitas di ruang angkasa bertanggung jawab atas semua kegiatan yang dilakukan. Hal ini semakin memperkuat bahwa setiap kegiatan di ruang angkasa harus tetap dalam pengawasan dan perawatan yang berkesinambungan.

Hal ini semakin diperkuat dengan adanya Pasal VII yang menyebutkan bahwa kegagalan negara di ruang angkasa dalam melaksanakan kewajibannya akan menghasilkan tanggung jawab yang menyebabkan timbulnya ganti rugi. Maka jelaslah bagaimana tanggung jawab negara terhadap kegiatannya di ruang angkasa.

Unsur kedua dari Pasal VI adalah aktivitas negara di ruang angkasa harus tunduk pada ketentuan yang ada di Outer space treaty dan juga ketentuan hukum internasional pada umumnya. Keharusan untuk tunduk pada Outer space treaty berarti keharusan untuk tunduk pada prinsip-prinsip yang ada. Terdapat beberapa prinsip yang ada di Outer space treaty 1967 antara lain: ${ }^{15}$

a. Prinsip non-diskriminasi, yaitu bahwa antariksa termasuk bulan dan benda langit lainnya harus dimanfaatkan untuk kepentingan semua bangsa tanpa membeda-bedakan tingkat ekonomi dan teknologi di antara mereka, semua negara berhak untuk melakukan aktivitas di dalamnya.

b. National non-apropriation principle, dengan prinsip ini maka tertutuplah setiap usaha negara untuk melakukan klaim kepemilikan atas bagian manapun dari antariksa termasuk bulan dan benda langit lainnya baik melalui kedaulatan maupun pendudukan

c. Rule of Law, bahwa kegiatan negaranegara dalam kaitannya dengan antariksa harus berlandaskan hukum internasional termasuk piagam PBB demi memelihara perdamaian dan keamanan dunia

d. Prinisp Perdamaian, bahwa negara tidak diperbolehkan meletakkan senjata berbentuk apapun yang dapat mengakibatkan kerusakan masal maupun senjata jenis apapun yang berbahan nuklir. Tidak diperbolehkan pula melengkapi benda angkasanya dengan peralatan demikian.

e. Prinsip kemanusiaan, bahwa setiap negara harus saling membantu apabila kemudian terjadi sebuah kecelakaan,

15 E. Saefullah Wirapradja, Pengantar Hukum Udara dan Ruang Angkasa, (Bandung: Alumni, 2014), hlm. 10. 
panggilan bantuan, atau pendaratan darurat oleh astronot yang terjadi di wilayah laut bebas atau wilayah territorial sebuah negara.

f. Prinsip tanggung jawab, bahwa semua negara dibebani tanggung jawab untuk menaati semua isi dari perjanjian ini dan untuk memberikan ganti rugi apabila aktivitasnya di ruang angkasa membahayakan pihak yang lainnya.

g. Prinsip persamaan, yaitu bahwa antariksa termasuk bulan dan benda langit lainnya dinyatakan bebas untuk dimanfaatkan setiap negara atas dasar persamaan.

h. Prinsip kerjasama, yaitu bahwa kerja sama antar negara harus dilandasi kebebasan untuk melakukan penelitian ilmiah atas antariksa termasuk bulan dan benda langit lainnya.

i. Prinsip keterbukaan, yaitu setiap negara yang melakukan kegiatan di ruang angkasa harus memberikan kesempatan bagi wakil negara lain yang ingin melakukan kunjungan atau pembelajaran bersama dengan dasar timbal balik dan saling menguntungkan.

Melihat pada prinsip-prinsip yang lahir dari Outer space treaty, salah satu prinsip utama adalah larangan kepemilikan terhadap ruang angkasa seperti yang terdapat pada pasal II yang berbunyi seperti berikut.

"Outer space, including the Moon and other celestial bodies, is not subject to national appropriation by claim of sovereignty, by means of use or occupation, or by any other means."

Prinsip larangan kepemilikan terhadap ruang angkasa mempertegas bahwa sesungguhnya ruang angkasa dapat digunakan oleh negara manapun dan tidak ada negara yang berhak melakukan klaim kedaulatan di ruang angkasa. Ruang angkasa bebas digunakan untuk kepentingan bersama umat manusia atau lebih dikenal dengan istilah common heritage of mankind.

Konsep common heritage of mankind atau milik bersama umat manusia, merupakan sebuah konsep yang sifatnya umum dalam keberadaan dan perkembangan hukum internasional. Konsep ini menjelaskan bahwa terdapat suatu wilayah yang mana wilayah tersebut menjadi milik bersama umat manusia. Sumber daya yang dihasilkan di wilayah tersebut dapat digunakan oleh semua orang dan untuk keuntungan semua orang. Hasil dari wilayah tersebut diharapkan dapat memenuhi kebutuhan dari negara berkembang maupun kebutuhan bagi generasi yang akan datang. Hal ini dimaksudkan supaya penggunaan wilayah tersebut dapat digunakan untuk pembangunan yang berkelanjutan utamanya terhadap keberlangsungan dan keberadaan sumber daya yang dihasilkan. ${ }^{16}$

Beberapa poin dasar dari wilayah yang disebut kepentingan bersama umat manusia itu antara lain, 
a. Tidak ada satu negara atau seorangpun yang dapat memiliki wilayah maupun sumber daya alamnya. Wilayah maupun sumber daya alam tersebut dapat digunakan, namun tidak untuk dimiliki. Hal ini dikarenakan wilayah tersebut adalah bagian dari warisan bagi dunia internasional dan menjadi milik semua umat manusia. Ini melindungi wilayah tersebut dari segala kepentingan negara manapun yang ingin memperlebar wilayah yurisdiksinya.

b. Penggunaan wilayah tersebut harus didasarkan pada kemauan untuk bekerja sama antar pengguna demi keuntungan seluruh umat manusia. Hal ini dimaksudkan untuk membangun sebuah hubungan kepercayaan antar negara yang melindungi kepentingan seluruh umat manusia daripada kepentingan maupun keuntungan sekelompok orang saja. Setiap negara yang memanfaatkan wilayah ini harus saling berbagi atas keuntungan yang diterima akibat aktivitasnya.

c. Wilayah harus digunakan untuk kepentingan perdamaian. Kegiatan militer pada wilayah ini tidak diperbolehkan.

d. Penggunaan wilayah tersebut harus terus dipelihara supaya dapat digunakan hingga masa yang akan datang. Termasuk memberikan perlindungan terhadap ekologi dan kesamaan antara generasi sekarang dan generasi berikutnya ${ }^{17}$

Pada poin terakhir jelas dijelaskan bahwa penggunaan wilayah common heritage of mankind, dalam hal ini ruang angkasa, harus tetap memperhatikan kegunaannya di kemudian hari. Bukan itu saja, kegiatan di ruang angkasa juga harus memberikan perlindungan terhadap keadaan lingkungan. Dalam hal ini bukan saja lingkungan ruang angkasa namun juga lingkungan bumi secara keseluruhan.

Keberadaan sampah ruang angkasa yang semakin banyak jumlahnya adalah hasil dari makin maraknya kegiatan negara di ruang angkasa. Sampah ruang angkasa pada tulisan ini adalah benda-benda angkasa yang sudah tidak berfungsi lagi namun tetap dibiarkan berada di orbit bumi. Benda angkasa seperti satelit, stasiun ruang angkasa atau mesin peluncur yang sudah tidak terpakai lagi itulah yang kemudian disebut sebagai sampah ruang angkasa. Benda-benda tersebut tidak jatuh ke bumi namun tetap mengorbit dengan beberapa kemungkinan yang membahayakan.Sampah ruang angkasa dalam pengertian ini antara lain:

a. Satelit yang telah habis masa pakainya

b. Kendaraan ruang angkasa yang tidak berfungsi lagi

c. Partikel hasil peluncuran benda angkasa yang sudah tidak terpakai

17 Prue Taylor, "The Common Heritage of Mankind: A Bold Doctrine Kept Within Strict Boundaries", http:// wealthofthecommons.org/essay/common-heritage-mankind-bold-doctrine-kept-within-strict-boundaries, diakses 10 Oktober 2015. 
d. Pecahan benda angkasa sisa misi ruang angkasa

e. Kepingan atau serpihan benda angkasa

Dalam kasus keberadaan sampah-sampah ruang angkasa yang bertebaran di orbit bumi menunjukkan bahwa negara pengguna ruang angkasa tidak menjalankan kewajibannya dengan baik. Menurut prinsip di Outer space treaty disebutkan bahwa wilayah ruang angkasa adalah milik bersama seluruh umat manusia ( common heritage of mankind). Hal ini menunjukkan bahwa segala kegiatan negara tetap harus menghormati hak-hak negara lain atas wilayah tersebut, karena semua negara berhak untuk beraktivitas di dalamnya.

Jika keberadaan sampah ruang angkasa semakin banyak, dan efek tabrakan yang ditakutkan terjadi, bukan hanya benda angkasa saja yang terancam keberadaannya. Benda angkasa yang jatuh ke bumi juga dapat mengancam lingkungan di permukaan bumi. Hal inilah yang tidak diinginkan untuk terjadi.

Jika merujuk pada pasal VII, telah dibuat sebuah perjanjian internasional lain yang bertujuan untuk memberikan perlindungan terhadap kerugian hasil berkegiatan di ruang angkasa. Namun meskipun ada perlindungan yang telah diakomodir di Liability Convention 1972, tetap saja tidak ada satu negarapun yang berharap benda angkasa menimpa wilayah negaranya. Maka dari itu keberadaan sampah ruang angkasa yang semakin banyak jumlahnya harus dikontrol keberadaannya. Pada saat ini, dari masih banyaknya jumlah benda angkasa tidak aktif yang ada di orbit bumi, dapat disimpulkan bahwa negara peluncur masih belum mampu menjalankan kewajibannya seperti apa yang diamanahkan oleh Outer space treaty 1967 sebagai dasar hukum ruang angkasa.

\section{B. Peraturan Baru Diperlukan untuk Mengontrol Keberadaan Sampah Ruang Angkasa}

Outer space treaty sebagai dasar prinsip kegiatan negara di ruang angkasa telah berusia 48 tahun. Selama 48 tahun itu pula teknologi negara untuk berkegiatan di ruang angkasa telah meningkat dengan pesat. Bersamaan dengan meningkatnya kegiatan tersebut tentunya semakin banyak pula permasalahan yang muncul. Terutama di wilayah ruang angkasa yang mana membutuhkan teknologi tinggi untuk melakukan aktivitas di dalamnya. Salah satunya adalah semakin banyaknya sampah ruang angkasa yang bertebaran di orbit bumi.

Melihat fakta seeperti ini, United Nation Convention On Peaceful Uses of Outer Space ( UNCOPUOS ), melalui salah satu badannya yang disebut Inter-Agency Space debris Coordination Committee (IADC) tidak menutup mata. Mereka telah menerbitkan sebuah panduan tentang hal-hal yang mungkin dilakukan oleh negara peluncur untuk mengurangi jumlah sampah ruang angkasa yang mungkin muncul di kemudian hari. Namun panduan tersebut berisi hal-hal yang sebaiknya dilakukan sebelum adanya 
peluncuran, tindakan-tindakan yang sifatnya preventif atau pencegahan. Selain sifatnya untuk pencegahan, isi dari buku panduan ini sifatnya adalah teknis. Lebih kepada panduan praktis yang sebaiknya dilakukan negara untuk mengurangi keberadaan sampah angkasa sedini mungkin. Tentunya instrumen hukum yang menjamin kepastian juga diperlukan, supaya semua pihak menaatinya. Permasalahannya adalah keberadaan sampah ruang angkasa ini telah cukup banyak jumlahnya. Diperlukan mekanisme kontrol terhadap permasalahan yang telah terjadi.

Setelah melihat pada rumusan permasalahan pertama di mana negara belum dapat memenuhi kewajiban atas outer space treaty, maka kiranya perlu dibuat perjanjian yang sifatnya lebih khusus lagi. Selain outer space treaty sebagai perjanjian induk ada beberapa perjanjian lain yang mengikuti. Perjanjian tersebut antara lain:

a. Agreement on the Rescue of Astronauts, the Return of Astronauts and the Return of Objects Launched into Outer Space. Perjanjian ini mengatur tentang prosedur pemberian bantuan kepada astronot atau objek dari benda angkasa yang mengalami kerusakan atau keadaan genting lainnya.

b. Convention on International Liability for Damage Caused by Space Objects. Konvensi ini mengatur bentuk tanggung jawab yang ditanggung oleh negara peluncur apabila kegiatannya mengakibatkan kerugian bagi negara atau pihak yang lain.

c. Convention on Registration of Objects Launched into Outer Space. Konvensi ini mengatur cara-cara pendaftaran benda angkasa supaya menjadi jelas kepemilikin dari benda angkasa tersebut. d. Agreement Governing the Activities of States on the Moon and Other Celestial Bodies. Perjanjian ini mengatur tentang kegiatan negara di bulan dan benda langit yang ada di ruang angkasa.

Hal ini dimaksudkan untuk memperjelas dan mempertegas isi dari outer space treaty itu sendiri. Maka dari itu pembuatan perjanjian yang khusus mengatur tentang lingkungan yang mendukung kegiatan di ruang angkasa perlu untuk dibuat. Supaya semakin jelas pula kelangsungan untuk kegiatan di ruang angkasa pada masa yang akan datang.

Terjadinya beberapa permasalahan tentang tertabraknya satelit yang masih aktif oleh space debris seharusnya sudah cukup menjadi acuan badan ruang angkasa yang ada di Perserikatan Bangsa-Bangsa supaya ada ketegasan hukum. Diharapkan dengan adanya instrumen hukum berupa perjanjian internasional maka negara yang melakukan aktivitas dapat menjalankan kewajibannya di ruang angkasa serta di lain sisi memberikan perlindungan hukum yang jelas kepada semua negara.

Sebagai dasar pembuatan perjanjian internasional terdapat tiga unsur yang harus dipenuhi. Ketiga unsur tersebut antara lain unsurfilosofis, yang menjadi dasar dibentuknya suatu perjanjian. Unsur yuridis yang berisi tentang dasar hukum yang digunakan untuk membuat perjanjian serta unsur politis yang menjadi tujuan dari pembuatan perjanjian internasional.

Semakin berkembang dan banyaknya kegiatan negara di ruang angkasa membuat 
kepadatan benda angkasa di orbit meningkat pesat. Sementara itu kegiatan negara di ruang angkasa tentunya akan terus berkembang dari masa ke masa. Untuk mengontrol hasil dari kegiatan negara di ruang angkasa inilah diperlukan peraturan yang sifatnya lebih pasti. Adanya peraturan yang pasti, membuat setiap negara yang berkegiatan di ruang angkasa akan lebih berhati-hati dan memikirkan kelangsungan dari lingkungan ruang angkasa. Maka dari itu ruang angkasa dapat menjadi tempat yang aman dan nyaman bagi semua negara yang ingin melakukan kegiatan di ruang angkasa sehingga generasi selanjutnya tetap dapat memanfaatkan ruang angkasa dengan sebaik-baiknya. Ini menjadi landasan filosofis atas perjanjian yang akan dibentuk.

Negara mengemban tanggung jawab secara internasional untuk mematuhi seluruh isi perjanjian dalam berkegiatan di ruang angkasa. Ini merupakan salah satu prinsip yang harus dipenuhi oleh negara. Dalam hal ini, negara belum bisa memenuhi kewajibannya karena dianggap lalai dalam menjaga lingkungan ruang angkasa dari potensi bahaya yang mungkin dihasilkan oleh sampah ruang angkasa. Ini berarti negara belum bisa melaksanakan prinsip-prinsip kegiatan di ruang angkasa seperti yang diinginkan outer space treaty.

Dengan dibentuknya perjanjian khusus yang mengatur tentang pengontrolan sampah di ruang angkasa diharapkan setiap negara yang berkegiatan dapat lebih bertanggung jawab atas kegiatannya tersebut. Sehingga negara bukan hanya menggunakan ruang angkasa dengan sebebas-bebasnya tanpa memikirkan akibatnya. Perlu juga dibuat sebuah aturan kerjasama antar semua pihak yang melakukan kegiatan di ruang angkasa sehingga terjadi suatu hubungan saling membantu antar mereka. Terutama bagi negara-negara maju yang memiliki teknologi tinggi di ruang angkasa juga harus memberikan bantuan-bantuan dengan sebaikbaiknya apabila ada suatu permasalahan. Hal ini semakin meningkatkan prinsip kerjasama negara di ruang angkasa.

Tiga hal yang menjadi dasar tersebut tentunya dapat menjadi alasan untuk segera dibentuk suatu pengaturan yang mengontrol keberadaan sampah ruang angkasa.

\section{Simpulan}

Berdasarkan pembahasan di atas maka dapat diambil beberapa kesimpulan sebagai berikut.

1. Negara memiliki sebuah kewajiban untuk menaati isi dari perjanjian internasional. Dalam hal ini, perjanjian yang menjadi induk kegiatan negara di ruang angkasa adalah outer space treaty 1967. Perjanjian tersebut berisi prinisp-prinsip yang menjadi acuan bagi negara yang berkegiatan di ruang angkasa. Saat ini negara yang berkegiatan di ruang angkasa belum bisa melaksanakan kewajiban seperti yang diminta oleh hukum ruang angkasa. Keberadaan sampah ruang angkasa yang semakin banyak dan 
membahayakan benda angkasa yang lain menjadi bukti bahwa negara tidak menjalankan kewajibannya untuk memelihara wilayah ruang angkasa yang semestinya menjadi common heritage of mankind.

2. Pada dasarnya UNCOPUOS sebagai bagian dari PBB yang khusus membahas permasalahan di ruang angkasa telah menyadari keberadaan sampah ruang angkasa yang semakin banyak jumlahnya. Namun hingga saat ini badan tersebut hanya membuat sebuah panduan untuk mengurangi dampak kegiatan ruang angkasa yang sifatnya teknis saja. Selain itu panduan tersebut sifatnya hanya prefentiv saja, padahal pada kenyataannya jumlah sampah ruang angkasa yang ada di orbit sudah ribuan jumlahnya. Diperlukan sebuah instrumen hukum berupa perjanjian internasional baru yang khusus untuk mengatur dan mengontrol sampah ruang angkasa yang ada di orbit. Dibuatnya instrumen hukum perjanjian internasional tersebut diharapkan melahirkan kepastian hukum yang harus ditaati oleh semua negara yang berkegiatan di ruang angkasa.

\section{DAFTAR PUSTAKA}

\section{Buku}

Baslar, Kemal. The Concept of the Common heritage of mankind in International Law. The Hague, The Netherlands: Kluwer Law International, 2012.

Brownlie, Ian. Principles of Public International Law. New York: Oxford, 2003.

Malcolm, Shaw N. Hukum Internasional. Bandung: Nusa Media, 2013.

Starke, J.G. Pengantar Hukum Internasional. Jakarta: Sinar Grafika, 2010.

Supriyadi, Dedi. Hukum Internasional dari Konsepsi sampai Aplikasi. Bandung: Pustaka Setia, 2013.

Tchatkova, Stella. Space Based Technology and Commercials Development. New
York: Engineering Science Reference, 2011.

Verschoor, Diederiks. Beberapa Persamaan dan Perbedaan Antara Hukum Udara dan Hukum Ruang Angkasa. Terjemahan oleh Bambang Iriana. Jakarta: Sinar Grafika, 1991.

Wirapradja, E. Saefullah. Pengantar Hukum Udara dan Ruang Angkasa. Bandung: Alumni, 2014.

\section{Jurnal}

Swinerd, H. G. Lewis, G. G. and R. J. Newland. "Space Debris Represents a Significant Risk To Satellite Operations", Aeronautical Journal (2011): 1166. 


\section{Naskah Internet}

Anonim. "Berapa Jumlah Satelit Yang Mengorbit Bumi”, http://www. amazine.co/14488/berapa-jumlahsatelit-yang-mengorbit-bumi/. Diakses 28 Maret 2015.

BBC. "Ecuador Pegasus Satellite Fears Over Space Debris Crash". http:// www.bbc.com/news/world-latinamerica-22635671. Diakses 28 Maret 2015.

BBC. "Russian and US Satellite Collide", http://news.bbc.co.uk/2/hi/7885051. stm. Diakses 28 Maret 2015.

Futurism. "The Seriousness of the Kessler Syndrome". http://futurism.com/ the-seriousness-of-the-kesslersyndrome. Diakses 28 Maret 2015.

Listner, Michael J. "Legal Issues Surrounding Space Debris Remediation." http://www.thespacereview.com/ article/2130/1. Diakses 26 Maret 2016.
Sattel Technologies. "The Historic Journey of Palapa B2”. http://www.sattel.com/ life_of_palapa_b2.htm. Diakses 28 Maret 2015.

Tate, Karl. "Space Junk Explained: How Orbital Debris Threatens Future of Spaceflight". http://www.space. com/23039-space-junk-explainedorbital-debris-infographic.html. Diakses 28 Maret 2015.

Taylor, Prue. "The Common heritage of mankind: A Bold Doctrine Kept Within Strict Boundaries". http:// wealthofthecommons.org/essay/ common-heritage-mankind-bolddoctrine-kept-within-strict-boundaries. Diakses 10 Oktober 2015.

Vone, Michelle La. "The Kessler Syndrome: 10 Interesting and Disturbing Facts". http://www.spacesafetymagazine. com/space-debris/kessler-syndrome/. Diakses 28 Maret 2015. 